\title{
UPAYA MENINGKATKAN KETRAMPILAN MENCOLET DAN HASIL BELAJAR MEMBATIK MELALUI MODEL PEMBELAJARAN CONTEXTUAL TEACHING AND LEARNING BERBANTUAN VIDEO ${ }^{2}$
}

\author{
Endriyani \\ endri.yanihartono@gmail.com \\ SMPN 2 Gedangsari - Gunungkidul
}

\begin{abstract}
ABSTRAK
Penelitian ini berangkat dari keadaan awal siswa di kelas 7 SMP Negeri 2 Gedangsari pada mata pelajaran keterampilan batik yang masih kurang memuaskan. Dari 34 siswa yang termasuk kategori terampil hanya 5 orang $(14,7 \%)$, dan siswa yang mendapatkan nilai tes diatas KKM (75) hanya sebanyak 14 orang $(41 \%)$. Hal ini disebabkan karena pembelajaran masih berpusat pada guru, dan metode yang digunakan masih konvensional. Tujuan penelitian ini adalah untuk meningkatkan keterampilan mencolet batik dan hasil belajar siswa kelas VIII B melalui model pembelajaran CTL berbantuan video. Penelitian ini adalah Penelitian Tindakan Kelas dengan model Kemmis dan Taggart yang terdiri dari dua siklus. Setiap siklus terdiri dari perencanaan, pelaksanaan, observasi, dan refleksi. Indikator keberhasilan penelitian adalah $80 \%$ siswa terampil mencolet batik, dan mendapatkan nilai diatas KKM. Hasil penelitian menunjukkan bahwa terjadi peningkatan keterampilan mencolet dan hasil belajar keterampilan dari siklus I ke siklus II. Pada siklus I, siswa yang termasuk kategori terampil meningkat menjadi 15 orang (44\%), dan siswa yang mendapatkan hasil belajar diatas KKM sebanyak 25 orang (73,5\%). Sedangkan pada siklus II, siswa yang termasuk kategori terampil sebanyak 28 orang (82\%), dan siswa yang mendapatkan hasil belajar diatas KKM meningkat menjadi 32 orang (94\%). Dengan demikian dapat disimpulkan bahwa penggunaan model CTL berbantuan video dapat meningkatkan keterampilan mencolet batik dan hasil belajarnya, sehingga disarankan untuk digunakan.
\end{abstract}

Kata kunci: $C T L$, Keterampilan Mencolet, Hasil Belajar

\section{PENDAHULUAN}

Batik merupakan salah satu produk budaya bangsa Indonesia yang dapat berfungsi sebagai bahan sandang dan penghias rumah. Sebagai salah satu produk asli, Bangsa Indonesia dituntut untuk melestarikan dan mengembangkan batik sebagai kekayaan seni. Akhir-akhir ini batik sedang digemari mulai dari kalangan muda hingga orang yang sudah tua. Tetapi kesenangan tersebut hanya sebatas trend

\footnotetext{
${ }^{2}$ Artikel ini telah diseminarkan dalam Seminar Nasional dan Gelar Produk Penelitian \& PPM pada tanggal 20-21 April 2015 di Universitas Negeri Yogyakarta
} 
saja, tidak dibarengi dengan kesadaran memelihara batik sebagai seni tradisional yang perlu dilestarikan.

Berbagai kendala terkait dengan pelestarian batik ini dihadapi, baik oleh para pengusaha, desainer, dan perajin. Permasalah ini timbul salah satunya adalah kurangnya minat masyarakat untuk memroduksi batik (khususnya batik tulis), dan cenderung hanya mengonsumsi batik atau menggunakannya. Selain itu, semakin berkembangnya batik printing dengan pesat, kurangnya minat generasi penerus pada usaha batik tulis, ketidak tersediaan bahan dan modal, serta lemahnya strategi pemasaran membuat batik tulis menjadi kian terpuruk. Demikian juga menurut Loupias (2007), bahwa keberadaan batik tradisional kini mulai surut sehingga perlu dipertahankan agar tidak punah. Pertimbangannya bukan sekadar dari sisi bisnis tetapi kerajinan tersebut merupakan aset kerajinan tradisional kita yang kian langka akibat terdesak oleh ekonomi kapitalis. Berdasarkan hasil penelitian di atas, maka kiranya perlu dicari jalan keluarnya agar batik dapat dilestarikan.

Salah satu cara yang dilakukan adalah menjadikan keterampilan membatik sebagai salah satu materi pilihan dalam mata pelajaran ketrampilan di SMP (khususnya di SMP-SMP yang terletak di area konsentrasi batik. Hal ini merupakan salah satu wujud kepedulian dalam usaha melestarikan budaya bangsa. Menurut Permendiknas RI No. 41 Tahun 2007 tentang Standar Proses Untuk Satuan Pendidikan Dasar dan Menengah, mata pelajaran keterampilan diarahkan agar peserta didik dapat mengembangkan kecakapan hidup (life skills) yang meliputi keterampilan personal sosial prafokasional dan akademik.Penekanan jenis keterampilan disesuaikan dengan mempertimbangkan minat dan bakat peserta didik serta potensi lokal, lingkungan budaya kondisi ekonomi dan kebutuhan daerah. Dengan adanya mata pelajaran ini, diharapkan sebagian masyarakat (dalam hal ini siswa) memiliki keterampilan yang baik dalam hal membatik, khususnya batik tulis.

Membuat batik tulis dengan teknik tradisional dan alat-alat tradisional (seperti canting dan bahan-bahan zat warna) memiliki tingkat kesulitan dan kerumitan yang tinggi. Hal ini membuat pengajaran materi pembuatan batik ini memerlukan waktu lama. Kegiatan mengerjakan batik tulis cukup rumit sehingga mesti teliti dan sabar karena prosesnya menuntut demikian. Semakin banyak warna yang ditargetkan, akan berdapak pada semakin sering membuka dan menutup malam. Proses penutupan malam tersebut mesti dilakukan pada kedua bidangnya atau bolak-balik. Disamping itu, limbah hasil pembuangan zat warna dan malam (lilin untuk membatik) sisa lorodan jika tidak dikelola dengan baik dapat menyebabkan polusi pada lingkungan sekitar.

SMP Negeri 2 Gedangsari merupakan salah satu sekolah di Daerah Istimewa Yogyakarta yang mengajarkan keterampilan membatik bagi siswanya. Sekolah ini berada di kecamatan Gedangsari, yang sebagian masyarakatnya, termasuk sebagian orang tua siswa bermata pencaharian sebagai pengusaha maupun 
pengrajin batik. Sekolah sudah dilengkapi dengan berbagai fasilitas penunjang seperti tempat tersediri (diluar kelas), sistem pengolahan limbah batik, tempat menjemur, dan berbagai peralatan yang diperlukan seperti kuas, ember, gelas takar, dan sebagainya. Selain itu, dalam pelajaran batik, setiap siswa mendapatkan fasilitas berupa selembar kain kosong untuk masing-masing siswa, kuas, lilin, cat, dan sebagainya. Dengan adanya fasilitas yang lengkap, didukung dengan guru yang berpengalaman, secara logis siswa dapat membatik dengan terampil dan mendapatkan hasil belajar membatik yang tinggi.

Kenyataan yang ditemui dilapangan, siswa SMPN 2 Gedangsari banyak kurang terampil dan mendapatkan hasil belajar yang rendah dalam keterampilan membatik. Terkait dengan keterampilan membatik, dari 34 siswa yang termasuk kategori terampil hanya 5 orang $(14,7 \%)$. Sedangkan terkait dengan hasil belajar, siswa yang mendapatkan nilai tes diatas KKM (75) hanya sebanyak 14 orang $(41 \%)$.

Hal di atas inilah yang membuat peneliti berupaya untuk mencari solusi mengatasi permasalahan tersebut. Berdasarkan berbagai kajian yang telah dilakukan, peneliti bertekad untuk meningkatkan kualitas pembelajaran batik di SMP Gedangsari melalui penggunaan pembelajaran kontekstual berbantuan video. Penggunaan metode ini dilakukan dalam materi mewarnai batik dengan metode colet. Metode ini untuk anak SMP Gedangsari merupakan pengembangan baru sebagai pelajaran batik dalam memperkaya pewarnaan batik. Sejauh ini telah diajarkan pewarnaan sintetis, alami. Sedangkan metode colet diajarkan karena efisien dan bersih lingkungan dalam pembuatannya dan memperkaya pengetahuan anak tentang pewarnaan batik. Keunggulan dari teknik colet adalah warna yang dihasilkan dalam satu helai batik bisa bermacam-macam. Penggunakan warna relatif lebih hemat. Warna yang dihasilkan cerah, bisa memilih mana batikan yang ingin dicolet dan mana yang tidak, bisa menghemat air. Sedangkan kelemahan dari teknik ini adalah membutuhkan waktu yang relatif lama tergantung berapa banyak motif yang ingin dicolet, warna bisa meluber ke motif lain dan kadang antara warna keinginan dan hasil tidak sama dan warna tidak rata dan cenderung tidak terlalu kuat menempel pada kain jika tidak telaten mengulang warna. Teknik colet sering kita temui pada batik pesisiran yang memang memiliki ciri warna-warna yang cerah. Seperti batik Pekalongan, batik Gresik, batik Madura, batik Indramayu dan daerah-daerah lainnya. Batik yang demikian itu yang banyak digemari dikalangan muda saat ini

Siswa perlu ketelitian dan kesabaran yang tinggi, dan tidak lupa tentang pencampuran warna dalam teknik mencolet ini supaya warna yang dihasilkan dari pewarnaan ini menjadi lebih cerah. Untuk mengembangkan keterampilan tersebut, maka peniliti menggunakan video pembelajaran tentang mencolet dengan metode CTL dengan tujuan siswa dapat langsung mengamati. Diharapkan setelah melihat 
video hasil pembelajaran mencolet anak lebih baik terarah, menarik dan indah dipandang.

Pembelajaran CTL dianggap paling cocok untuk pelajaran ini berdasarkan berbagai pertimbangan. Sudrajat (2007), menyatakan bahwa Contextual Teaching and Learning (CTL) merupakan suatu proses pendidikan yang holistik dan bertujuan memotivasi siswa untuk memahami makna materi pelajaran yang dipelajarinya dengan mengkaitkan materi tersebut dengan konteks kehidupan mereka sehari-hari (konteks pribadi, sosial, dan kultural) sehingga siswa memiliki pengetahuan/keterampilan yang secara fleksibel dapat diterapkan (ditransfer) dari satu permasalahan/konteks ke permasalahan/konteks lainnya. Pengertian tersebut menunjukkan bahwa pengetahuan yang ada dalam diri siswa dapat diterapkan kedalam masalah yang sifatnya kontekstual. Hal ini sesuai dengan kondisi yang ada, dimana sekolah terletak di daerah konsentrasi kerajinan batik. Dalam hal ini, metode learning community dipilih untuk digunakan dalam penelitian ini.

Suatu permasalahan tidak mungkin dapat dipecahkan sendirian, tetapi membutuhkan bantuan orang lain. Kerja sama saling memberi dan menerima sangat dibutuhkan untuk memecahkan suatu persoalan. Konsep masyarakat belajar (learning community) dalam CTL menyarankan agar hasil pembelajaran diperoleh melalui kerja sama dengan orang lain. Kerja sama itu dapat dilakukan dalam berbagai bentuk baik dalam kelompok belajar secara formal maupun dalam lingkungan yang terjadi secara alamiah. Hasil belajar dapat diperoleh dari hasil sharing dengan orang lain, antar teman, antar kelompok; yang sudah tahu memberi tahu pada yang belum tahu, yang pernah memiliki pengalaman membagi pengalamannya pada orang lain. Inilah hakikat dari masyarakat belajar, masyarakat yang saling membagi.

Supaya konsep saling sharing dan berbagi antar pihak yang berpengalaman dengan pihak yang belajar menjadi lebih efisien, maka diperlukan media yang tepat. Penelitian ini menggunakan video sebagai jembatan untuk sharing dari industri batik mengenai teknik mencolet yang baik kepada para siswa yang sedang belajar.

Berdasarkan latar belakang masalah tersebut maka judul penelitian ini adalah Upaya Meningkatkan Ketrampilan Mencolet Dan Hasil Belajar Membatik Melalui Metode Pembelajaran Contextual Teaching And Learning Berbantuan Video. Rumusan masalah dalam penelitian ini adalah: (1) Apakah keterampilan mencolet batik siswa dapat ditingkatkan melalui metode pembelajaran CTL learning community berbantuan video? (2) Apakah hasil belajar siswa pada mata pelajaran keterampilan dapat ditingkatkan melalui model pembelajaran CTL berbantuan video?

Berdasarkan rumusan masalah tersebut, tujuan dari penelitian ini adalah: (1) Meningkatkan keterampilan mencolet batik siswa melalui metode pembelajaran CTL berbantuan video. (2) Meningkatkan hasil belajar siswa pada mata pelajaran 
keterampilan melalui metode pembelajaran CTL berbantuan video. Selanjutnya, hasil penelitian ini bermanfaat bagi siswa untuk meningkatkan keterampilan mencolet dan hasil belajarnya, serta bagi guru sebagai alternatif pengajaran membatik.

Manfaat penelitian ini meliputi manfaat bagi siswa, guru, dan sekolah. Manfaat bagi siswa adalah meningkatkan keterampilan mencolet dan hasil belajar keterampilan. Sedangkan manfaat bagi guru adalah memerbaiki kualitas pembelajaran dan suksesnya pembelajaran yang dilakukannya. Bagi sekolah sebagai salah satu referensi untuk penyelenggaraan pembelajaran yang berkualitas.

\section{METODE PENELITIAN}

Penelitian ini dilaksanakan di kelas VIII B SMP Negeri 2 Gedangsari Gunungkidul. Mayoritas siswa SMP ini (75\%) berasal dari keluarga pra sejahtera. Setiap kelas rata-rata terdiri dari 34 siswa. Semua siswa diterima tanpa seleksi. Umumnya, mereka berasal dari daerah pegunungan dengan jarak rata-rata $6 \mathrm{~km}$ dari sekolah. Perjalanan ke sekolah biasanya mereka tempuh dengan berjalan kaki. Pekerjaan orang tua siswa mayoritas adalah petani dan buruh batik.

Di dalam penelitian ini, peneliti menggunakan model Penelitian Tindakan Kelas (PTK). Model PTK yang digunakan adalah Kemis dan Taggart (Suparno, 2008). Penelitian berlangsung dalam 2 siklus, dan sekali pra siklus pada setiap siklus dilakukan tiga kali pertemuan, dimana pertemuan pertama dan kedua digunakan untuk pembelajaran, dan pada pertemuan ke tiga digunakan untuk evaluasi. Setiap siklus terdiri dari langkah-langkah berikut: (1) perencanaan, (2) pelaksanaan pembelajaran sekaligus pengamatan, serta (3) refleksi terhadap tindak pembelajaran yang telah dilakukan.

Data yang dikumpulkan dalam penelitian ini muliputi data efektifitas proses pembelajaran dan data variabel dampak pembelajaran. Data efektifitas proses pembelajaran yang dikumpulkan meliputi data tentang tindak pembelajaran guru, dan data respons siswa terhadap pembelajaran. Data tentang tindak pembelajaran guru dikumpulkan melalui observasi oleh observer, dan data respons siswa diperoleh dari tulisan refleksi siswa, serta hasil wawancara peneliti dengan siswa. Semua data ini dipertimbangkan untuk kegiatan analisis dan refleksi, dan menentukan perubahan tindak pembelajaran yang diperlukan. Sedangkan data variabel dampak penelitian meliputi data keterampilan mencolet dan hasil belajar siswa. Data keterampilan mencolet dikumpulkan dengan cara memberikan tes praktik yang memerintahkan siswa mengubah batik menjadi model batik colet yang baru. Sedangkan data hasil belajar dilakukan dengan cara menilai hasil karya (batik buatan siswa) sesuai dengan pendapat dari Tafsir (2008:34-35) yang menyatakan bahwa hasil belajar adalah hasil akhir yang diharapkan dapat dicapai setelah 
seseorang belajar. Data-data yang telah terkumpul dianalisis secara deskriptif (Sugiyono, 2006).

Di dalam penelitian ini, indikator keberhasilan tindakan yang dijadikan pedoman adalah ketrampilan siswa mencolet batik. Tindak pembelajaran dianggap telah berhasil apabila sedikitnya $80 \%$ siswa mampu melakukan mencolet dengan benar minimal $60 \%$ karya dari praktik batik yang dilaksanakan pada setiap pertemuan. Sedangkan hasil belajar siswa dikatakan memenuhi kriteria keberhasilan jika 90\% siswa tuntas KKM. Jika tidak demikian, maka tindak pembelajaran dianggap gagal, dan perlu diperbaiki serta dicobakan pada siklus berikutnya. Sehubungan dengan indikator keberhasilan tersebut, data yang dikumpulkan di dalam penelitian ini adalah data tentang ketrampilan siswa dalam mencolet karya batik dan hasil belajar mencolet batik.

\section{HASIL DAN PEMBAHASAN}

Penelitian ini dilaksanakan dalam 2 siklus penelitian. Hal ini karena target dan kriteria keberhasilan telah tercapai pada siklus kedua. Pelaksanaan penelitian dan hasil yang dicapai nampak dari deskripsi berikut ini.

Kegiatan yang dilakukan dalam kedua siklus meliputi perencanaan, pelaksanaan dan pengamatan, serta refleksi. Berikut rincian kegiatan-kegiatan tersebut.

\section{Perencanaan Siklus I}

Kegiatan-kegiatan yang dilaksanakan dalam perencanaan pembelajaran siklus 1 diantaranya: (1) Menyiapkan izin penelitian; (2) Menghubungi dan berkoordinasi dengan kolaborator; (3) Menyusun perangkat perencanaan, khususnya Rencana Pelaksanaan Pembelajaran (RPP), dan Lembar Kerja; (4) Menyiapkan alat-alat praktikum mencolet; (5) Menyusun instrumen penilaian berupa lembar pengamatan proses, dan lembar pengamatan keterampilan siswa; (6) Menyediakan alat-alat penunjang pembelajaran, seperti laptop, LCD, video, dan kamera.

\section{Pelaksanaan Siklus I}

Pelaksanaan siklus 1 mengikuti langkah-langkah berikut: (1) Guru menjelaskan teori mencolet, dan contoh-contoh riil yang sering dilakukan oleh pengrajin di Gedangsari; (2) Siswa diberi Lembar Kerja dan kain kecil untuk latihan mencolet; (3) Siswa membuat motif; (4) Siswa memindah motif di kertas karkas; (5) Siswa praktik memindah motif dikain; (6) Bersama kelompoknya, praktik membatik membuat klowong; (7) Siswa melihat video pembelajaran tentang mencolet; (8) Siswa menanggapi video; (9) Siswa praktik mencolet dengan pengawasan guru. 


\section{Pengamatan Siklus I}

Pengamatan yang dilakukan pada siklus 1 dilakukan oleh observer, dengan menggunakan lembar observasi. Beberapa aspek yang diamati adalah efektifitas dan kualitas pembelajaran, serta keterampilan siswa dalam mencolet.

\section{Refleksi Siklus I}

Refleksi siklus 1 dilakukan oleh guru, observer, dan 2 orang siswa sebagai perwakilan. Refleksi ini dilakukan dengan cara diskusi kelompok terfokus. Hasil refleksi menunjukkan bahwa pembelajaran belum berlangsung efektif sesuai harapan. Dalam pertemuan ini teridentifikasi bahwa selama siklus I tersebut: (1) guru memperlihatkan video tidak disertai instruksi kepada siswa kurang jelas dan siswa kesulitan untuk memahami, (2) bimbingan yang diberikan guru kurang secara bertahap, yakni secara individual optimal, (3) guru berbicara terlalu cepat, (4) Lembar Kerja tidak diberi contoh atau informasi, dan (5) keterbacaan perintah tidak jelas. Masih banyak siswa yang tidak fokus mengikuti pelajaran, dan belum terampil dalam mencolet. Selain itu, karya yang dihasilkan juga masih belum sesuai harapan (hasil belajar belum sesuai target. Oleh karena itu, diputuskan untuk melanjutkan pembelajaran pada siklus kedua.

\section{Perencanaan Siklus II}

Perencanaan yang dilakukan di siklus 2 sama dengan perencanaan dalam siklus 1 . Hanya yang membedakan adalah Lembar Kerjanya. Selain itu, bahan yang diberikan pada siswa berupa kain sandang.

\section{Pelaksanaan Siklus II}

Pelaksanaan siklus 2 sama dengan pelaksanaan siklus 1. Hanya saja dalam siklus 2 ini pendampingan dari guru lebih ditekankan. Selain itu, siswa dituntut untuk mendeskripsikan keterampilan batik dan menulisnya. Pada siklus II peneliti melakukan perbaikan-perbaikan antara lain: (1) siswa dituntut untuk membuat penjelasan dalam LK, (2) guru mengamati proses pembuatan colet batik dan menunggu siswa hingga selesai, (3) LK diberi informasi/contoh darivideo terbimbing, (4) guru membimbing dengan cara mengunjungi semua kelompok dan memberikan pertanyaan arahan. Di samping itu, (5) jika pada siklus I siswa membuat secara berkelompok, pada siklus II diperbaiki jadi siswa membuat secara individual terlebih dahulu, kemudian hasilnya didiskusikan dengan kelompoknya, (6) Jika sebelumnya hasil kerja dipresentasikan di depan kelas, maka pada pertemuan ini dilakukan karya berkunjung ke kelompok lain dan saling komentar. 


\section{Pengamatan Siklus II}

Pengamatan yang dilakukan pada siklus kedua sama dengan pengamatan dalam siklus pertama. Observer yang mengamati adalah orang yang sama dengan siklus I, dan aspek yang diamati juga sama dengan siklus I.

\section{Refleksi Siklus II}

Refleksi yang dilaksanakan pada siklus 2 sama dengan refleksi yang dilaksanakan pada siklus 1 . Perbedaan yang terjadi adalah hasil refleksinya, dimana pada siklus 2 ini pembelajaran telah berjalan dengan lebih efektif, siswa cenderung lebih terampil mencolet, dan hasil karyanya lebih bagus. Oleh karena itu, pembelajaran dihentikan pada siklus kedua ini.

\section{Deskripsi Keterampilan Mencolet dan Hasil Belajar Siklus I dan II}

Berdasarkan data yang terkumpul, keterampilan siswa dalam mencolet mengalami peningkatan dari siklus ke siklus. Pada prasiklus (sebelum penelitian ini dilaksanakan), jumlah siswa yang termasuk kategori terampil hanya sebanyak 5 orang $(14,7 \%)$. Sedangkan pada siklus pertama, jumlah tersebut meningkat menjadi 15 orang (44\%), dan meningkat lagi menjadi 28 orang (82,3\%) pada siklus kedua.

Hasil belajar siswa (dalam hal ini nilai hasil karya siswa) juga mengalami peningkatan dari siklus ke siklus. Sebelum penelitian (prasiklus), hanya 14 orang $(41,1 \%)$ saja siswa yang dapat mencapai KKM. Angka tersebut meningkat menjadi 25 orang $(73,5 \%)$ pada siklus pertama, dan meningkat lagi menjadi 32 orang (94\%) pada siklus kedua. Tabel 1 berikut menyajikan data dari setiap siklus, deskripsinya dan kesimpulan refleksi yang dilakukan.

Tabel 1. Data Keterampilan dan Hasil Belajar

\begin{tabular}{|c|c|c|c|c|l|l|}
\hline Siklus & $\begin{array}{c}\text { Siswa } \\
\text { Terampil }\end{array}$ & $\%$ & $\begin{array}{c}\text { Siswa } \\
\text { mencapai } \\
\text { KKM }\end{array}$ & $\mathbf{\%}$ & Deskripsi & \multicolumn{1}{|c|}{$\begin{array}{c}\text { Sim- } \\
\text { pulan }\end{array}$} \\
\hline Prasiklus & 5 & 14.7 & 14 & 41,1 & $\begin{array}{l}\text { Jumlah siswa terampil belum } \\
\text { mencapai } 80 \% \text { dan ketuntasan } \\
\text { belum mencapai } 90 \%\end{array}$ & $\begin{array}{l}\text { Belum } \\
\text { berhasil }\end{array}$ \\
\hline Siklus 1 & 15 & 44 & 25 & 73,5 & $\begin{array}{l}\text { Jumlah siswa terampil belum } \\
\text { mencapai } 80 \% \text { dan ketuntasan } \\
\text { belum mencapai 90\% }\end{array}$ & $\begin{array}{l}\text { Belum } \\
\text { berhasil }\end{array}$ \\
\hline Siklus 2 & 28 & 82,3 & 32 & 82,3 & $\begin{array}{l}\text { Jumlah siswa terampil sudah } \\
\text { mencapai } 80 \% \text { dan ketuntasan } \\
\text { sudah mencapai } 90 \%\end{array}$ & $\begin{array}{l}\text { Berhasi } \\
1\end{array}$ \\
\hline
\end{tabular}




\section{Pembahasan Hasil Penelitian}

Penelitian ini menunjukkan bahwa pemberian kesempatan kepada siswa untuk menerjemahkan video yang membantu mereka memiliki kemampuan ketrampilan mencolet batik dengan baik. Ravianto (1985) berpendapat bahwa hasil kerja yang memuaskan tergantung dari kemampuan dan kecakapan kerja serta penguasaan dan pengetahuan, kecakapan, dan keterampilan melaksankan pekerjaan.

Hal penting lain yang diperoleh dari penelitian ini adalah dituliskannya di dalam LK berisi beberapa informasi dan contoh lengkap ternyata membantu meningkatkan ketrampilan siswa dalam mencolet batik. Hal ini sejalan dengan pendapat Supriyanto (2006) yang menyatakan bahwa LK yang dilengkapi dengan informasi, dapat meningkatkan kemampuan pemahaman siswa sebesar 30\%.

Terkait dengan meminta siswa untuk terlebih dahulu mengamati secara individual, menurut hemat peneliti ini akan memberikan kesempatan kepada siswa untuk mencoba memahami. Percobaan ini bisa berhasil tetapi juga bisa gagal. Akan tetapi, percobaan itu sendiri telah memberikan kesempatan kepada siswa untuk mengolah struktur kognitif yang dimilikinya. Skema di dalam struktur kognitifnya mungkin akan menjadi lebih kaya dan lebih terhubungkan. Dengan begitu, siswa siap untuk berdiskusi dengan teman kelompoknya, dan memperoleh pemahaman yang lebih baik.

Namun demikian, jika diperhatikan, kenaikan persentase siswa yang memraktekkan dengan benar minimal $60 \%$ dari tugas yang diberikan sebenarnya tidak terlalu tinggi. Salah satu faktornya mungkin adalah jumlah tugas di pertemuan 2 lebih banyak kesempatan dan waktu.

Banyak penelitian sebelumnya yang menempatkan model CTL secara strategis untuk meningkatkan kemampuan berpikir dan kemampuan kogntif lain. Namun, penelitian ini menunjukkan bahwa model CTL juga efektif digunakan untuk meningkatkan keterampilan secara konasi, yaitu keterampilan mencolet. Hal ini senada dengan penelitian dari Sutrisno (2010) yang juga menemukan bahwa pembelajaran $C T L$ efektif untuk meningkatkan keterampilan siswa dalam menulis karangan.

\section{SIMPULAN}

Berdasarkan hasil penelitian, disimpulkan bahwa penggunaan modelpembelajaran CTL berbantuan video dapat memerbaiki proses pembelajaran mata pelajaran keterampilan di kelas VIII B SMPN 2 Gedangsari, Gunungkidul. Efektifnya pembelajaran yang dilakukan berdampak pada peningkatan variabel dampak penelitian ini, yaitu keterampilan mencolet dan hasil belajar. Oleh karena itu, jawaban dari kedua rumusan masalah penelitian adalah: (1) Penggunaan model pembelajaran CTL learning community berbantuan video dapat meningkatkan keterampilan siswa dalam mencolet batik di kelas VIII B SMPN 2 Gedangsari; (2) 
Penggunaan model pembelajaran CTL berbantuan video dapat meningkatkan hasil belajar siswa dalam mata pelajaran keterampilan membatik di kelas VIII B SMPN 2 Gedangsari.

Berdasarkan simpulan tersebut, hasil penelitian menjadi saran bagi siswa, guru dan sekolah. Bagi siswa disarankan untuk belajar dari hal-hal yang sifatnya kontekstual, termasuk melihat video untuk dapat meningkatkan keterampilan membatik dan hasil belajarnya. Bagi guru disarankan untuk menggunakan model pembelajaran CTL berbantuan video untuk dapat memerbaiki pembelajaran yang dilaksanakan. Sedangkan bagi sekolah disarankan untuk menggunakan variasi metode dalam pembelajaran yang dilakukan supaya dapat mengakomodir berbagai kebutuhan siswa dan tujuan pembelajaran.

\section{DAFTAR PUSTAKA}

Loupias, H. 2007. Batik Tulis Tradisional Sunda Garutan. www.batiksunda. Blogspot.com

Permendiknas 41 Tahun 2007 Tentang Standar Proses Untuk Satuan Pendidikan Dasar dan Menengah

Sudrajat, A. 2007. Kurikulum dan Pembelajaran dalam Paradigma Baru. Yogyakarta: Paramitra Publishing

Sugiyono, 2006. Statistika Untuk Penelitian. Bandung: Alfabeta

Suparno, P. 2008. Riset Tindakan Untuk Pendidik. Jakarta: Grasindo

Tafsir, A. 2008. Strategi Meningkatkan Mutu Pendidikan Agama Islam di Sekolah. Bandung: Maestro

Sutrisno, Ari .2010. Upaya Meningkatkan Keterampilan Menulis Deskripsi Melalui Pendekatan Contextual Teaching and Learning (CTL) pada Siswa Kelas IVA SDN Dukuhan Kerten no. 58 Surakarta Tahun Ajaran 2009/ 2010. Thesis, Universitas Sebelas Maret. http://eprints.uns.ac.id/47/ 